\title{
Risk Based Internal Audit - An Empirical Model For Implementation
}

\author{
Mohammad Ali Bagherpour Velashani*, Mostafa Jahanbani ${ }^{* *}$ \\ Somayeh Zafarzade
}

Internal auditing plays an important role in the efficiency and effectiveness of internal control system in organizations. Internal auditing should provide correct information to management about effectiveness of risk management and internal controls including compliance with organizational laws and regulations. At this time, there are different types of internal auditing, which primarily accept and apply procedures such as testing transactions, testing accuracy and reliability of accounting books and financial reports, the accuracy, reliability and timeliness of control reports and testing compliance with legal and regulatory requirements. However, none of these offer an opinion about qualitative aspects of organizational management, especially risk management. Therefore, it is necessary to redefine internal auditing and to determine the new scopes for it in order to ensure from adoption of modern risk management tools, adequacy and effectiveness of these tools and also helping organizational units to reduce risks. These changes in focus and attention of internal auditing are possible by revision in attitudes to audit and changing it to risk-based internal auditing. Regarding this matter, the main purpose of this study is to provide a comprehensive and practical model for implementing and using risk-based internal auditing in companies and organizations. This model is designed based on theoretical principles presented in the literature and relevant research as well as professional experience of the authors. Also, the designed model has been implemented in one of the large Iranian organizations, which increases the value and applicability of the model.

Keywords: Internal audit, risk based internal auditing, risk assessment, risk management

Submitted: 06.11.2012 | Accepted: 27.12.2012

\section{Audyt wewnętrzy oparty na ryzyku}

Audyt wewnętrzny odgrywa znaczaca role $w$ systemie wewnętrznej kontroli wydajności i efektywności w organizacjach. Powinien dostarczać kadrze zarzadzajacej prawidtowe informacje na temat efektywności zarzadzania ryzykiem i kontroli wewnętrznych, $w$ tym zgodności z prawami i przepisami obowiazujacymi w organizacji. Obecnie istnieja różne rodzaje audytu wewnętrznego, które gtównie przyjmują i stosuja takie procedury jak sprawdzanie prawidto-

* Mohammad Ali Bagherpour Velashani - Ferdowsi University of Mashhad, Mashhad, Iran, Head of Research and Development Center of the Rahyaft and Partners (Audit and Management Consultancy Firm).

Correspondence address: Faculty of Economic and Administrative Sciences, Ferdowsi University of Mashhad, Azadi Square, Mashhad, Iran.

** Mostafa Jahanbani - CPA and CEO of the Rahyaft and Partners (Audit and Management Consultancy Firm).

Correspondence address: No.237, West Ebn-Sina Ave.Ferdowsi Blvd, Mashhad, Iran, P.O.Box:91375-4465.

*** Somayeh Zafarzade - Member of Research and Development Center of the Rahyaft and Partners (Audit and Management Consultancy Firm).

Contact author: Mohammad Ali Bagherpour Velashani, e-mail: Bagherpour@gmail.com. 
wości transakcji, sprawdzanie dokładności prowadzenia $i$ wiarygodności ksiag rachunkowych oraz raportów finansowych, sprawdzanie dokładności, wiarygodności i terminowości raportów $z$ kontroli oraz zgodności procedury kontroli $z$ wymaganiami prawnymi i regulaminowymi. Zadna z powyższych procedur nie umożliwia jednak wgladu $w$ aspekty jakościowe zarządzania organizacja a zwłaszcza zarzadzania ryzykiem. Konieczne jest zatem przedefiniowanie audytu wewnętrznego i określenie jego nowego zakresu w celu zapewnienia przyjęcia nowoczesnych narzędzi zarzqdzania ryzykiem, wspótmierności $i$ efektywności tych narzędzi oraz pomocy jednostkom organizacyjnym $w$ redukowaniu zagrożeń. Te zmiany w zainteresowaniu i uwadze poświęcanym przez audyt wewnętrzny sa możliwe przez zmianę podejścia do audytu i zmiane go $w$ audyt wewnętrzny oparty na ryzyku. Wnawiazaniu do tej kwestii, celem niniejszej pracy jest dostarczenie kompleksowego i praktycznego modelu implementacji $i$ stosowania audytu wewnętrznego opartego na ryzyku w firmach i organizacjach. Model ten zostat stworzony $w$ oparciu o zatożenia teoretyczne obecne $w$ literaturze $i$ stosowne badania oraz o doświadczenie zawodowe autorów. Ponadto, stworzony model zostat wdrożony $w$ jednej $z$ dużych organizacji w Iranie, co zwiększa jego wartość i potwierdza możliwość jego zastosowania.

Slowa kluczowe: audyt wewnętrzny, audyt wewnętrzny oparty na ryzyku, ocena ryzyka, zarządzanie ryzykiem

Nadesłany: 06.11.2012 | Zaakceptowany do druku: 27.12.2012

JEL: M42

\section{Introduction}

The methods and procedures of internal audit have been changed dramatically over past decade. This change was through system-based auditing to process-based auditing and now the focus is on risk-based internal auditing. Risk based internal auditing requires to identify organizational risks, therefore, result in optimum use of scarce audit resources, more coordination between internal auditors and management objectives, facilitating organizational development and decrease of probable risks by focusing on areas which have some weaknesses.

Regarding the growing role and importance of risk-based internal auditing in organizations and also lack of applying riskbased internal auditing in many of them, the main purpose of this research is to provide an empirical model for implementing risk-based internal auditing as well as identifying the requirements for implementation of it. The model was developed based on the related literature and professional experience of authors. Then the designed model was implemented in one of the large Iranian organizations. This matter results to identify and resolve (probable) shortages in designing of the model. Thus, presented model in this study has theoretical aspects and practical support. The model includes steps such as: determining control objectives, analyzing and prioritizing risks, control activities (necessary requirements to reduce risks), determining existing control weaknesses, providing audit programs, and conducting the required tests and providing audit reports.

This paper has three main contributions: (1) determining background and requirements for implementing and using risk-based internal auditing (2) providing the possibility of full implementing of risk management in companies and organizations (3) providing a comprehensive model for implementing risk-based internal auditing. In this regard, definitions and importance of internal audit in the organization and then classification of organizations according to their risk maturity as well as requirements for implementation of riskbased internal audit will be described. At the end, the empirical model for implementation of risk-based internal audit will be provided at detailed.

\section{Definitions and importance of internal audit in the organization}

There are different definitions of internal auditing. Internal auditing is a necessary mechanism, which prevents fraud and mistakes, ensure compliance with policies and procedures and increase efficiency and 
effectiveness (Eden and Moriah, 1996). Internal auditing compare real operation of organization with standards and expectations based on related criteria, and includes program and comprehensive procedures to help management team to improve organizational controls. Internal auditing traditionally is designed to ensure the reliability of financial information and to protect companies' assets. Recently, internal auditing has been developed, so that covers operational auditing, risk assessment, information technology assurance services and etc. This developed role has increased the importance of internal auditing as a part of risk management system in organization (Spira and Page, 2003). Association of Internal Auditors defines internal auditing as following:

"Internal auditing is an independent, objective assurance and consulting activity designed to add value and improve an organization's operations. It helps an organization accomplish its objectives by bringing a systematic, disciplined approach to evaluate and improve the effectiveness of risk management, control, and governance processes."

This definition illustrates a basic change in the role of internal auditors. This change shows that providing consulting services is one of important parts of internal auditing activities. The main purpose of internal auditing is to aware management from existence of a reasonable and effectiveness and efficient internal control system which can protect organization against losses which arise from risks that they cope with.

Board of directors in each organization has final responsibility to ensure from establishment an adequate and efficient internal control system and risk assessment system so that the risk of the organization can be determined, measured, monitored and controlled, although the executive responsible for creating and establishing such a system is with senior management in organization. In this field, Internal auditors can help board of directors and senior management in doing their work and efficiency of their responsibility by continuous monitoring of internal control by independent evaluation of the adequacy and compliance of policies and procedures which has been determined in organization (Basel Committee, 2000). According to international standards of internal auditing (2001) internal auditors should cooperate in evaluating and improving risk management and control processes by using a systematic and regular procedure and help organization in determining and evaluating probable risks and improving risk management and control systems. Internal auditors should evaluate the effectiveness of risk management systems of organization and possible risk of corporate governance, operations and information systems related to following items:

- Reliability and accuracy of financial and operating information

- Effectiveness and efficiency of operations

- Safeguarding of the assets

- Compliance with laws, regulations and contracts

Internal auditing should focus on risks regarding to the goals of investigation and should be aware of the existence of other important risks. However, the main role or responsibility of internal auditing is to provide independent assurance about whether the organization manages risk well or not. Internal auditors should be aware from significant risks, which may have consequences on objectives, activities or resources. However, just assurance procedures, even along with professional care, cannot ensure that all major risks are determined. Internal auditing provides insurance about the adequacy of existing controls to reduce risk, effectiveness and efficiency of control processes and realization of short and long term organizational objectives.

Internal auditors evaluate the adequacy and effectiveness of way of determining and managing risk based on the results of risk assessment. They also evaluate other aspects such as ethics principle and values in organization, performance management, transfer of data related to risk and control within organization to facilitate a good process of governance. While management is responsible for internal control, the internal auditors ensure management and audit committee that internal controls are efficient and act according to expectations. Internal auditing is a valuable resource for management, board of directors and audit committee. Objectivity, expertise and knowledge of internal auditors can significantly improve internal controls, risk management and the corporate governance process. Also, an efficient internal auditing 
can ensure other interested parties such as regulators, employees, creditors and shareholders.

\subsection{The role of internal auditors in corporate governance}

Internal auditors increasingly are wel1-known as important actors in corporate governance (Rezaee, 2009). New statistics provided by the Association of Internal Auditors (IIA) indicate increasing demand for internal auditors. Enactment (approval) and implementation of the Sarbanes-Oxley Act (SOX) is the main reason for increase in the number of IIA members and also to reveal the amazing value which internal auditor can add to their organizations.

Internal auditors play an important role in the Audit Committee (Smith, 2006), transfer pricing management (Dean et al., 2008), preventing Computer scams (Kratchman et al., 2008), application of International financial reporting standards (Smith et al, 2008), applying new technologies such as continuous auditing (Warren and Smith, 2006), reducing the workload and cost of the independent auditors (Gramling, 1999). Internal auditors can decrease auditing fees (costs) by: 1) improving company's internal control, 2) conducting financial tests (exams) which internal auditors can rely on them, and 3) providing overall help to auditors (Wallace, 1984). Internal auditors play a unique and essential role in corporate governance by monitoring organizational risks and help to ensure from reliability of financial reporting (Deloitte, 2005; Schneider and Wilner, 1990).

\subsection{The role of internal auditors in risk management}

Risk management is an important part of organizational strategic management. The focus of risk management is on determining and reducing risks and its purpose is to increase the maximum stable (continuous) value to all activities of organization. Risk management can increase the likelihood of success and achievement of overall objectives of organization. The risk can be defined as types of events or circumstances that may hinder the achievement of objectives (Roy, 2008). ISO (International Standards Organization) defines a risk as 'the combination of the probability of an event and its consequences'. Thus, deter- mining all possible risks in a process and their likelihood are the main parts of risk assessment in organization. On this basis, company's risk management can be defined as "A structured and continuous process across the entire organization for identifying, assessing, deciding on responses to and reporting on opportunities and threats that affect the achievement of its objectives". Thus, technically, risks can be either a threat, or an opportunity.

Nowadays, a greater emphasis on risk management, as a key factor in achieving organizational objectives, is placed. After recent bankruptcies of large companies due to financial irregularities, new laws such as the New York Stock Exchange, the Sarbanes - Oxley (2000), Public Company Accounting Oversight Board Public Company Accounting Oversight reinforced by standards of the Board (PCAOB), London Stock Exchange ${ }^{1}$, Turnbull Committee Guidance (TCG), have required companies which listed in the stock exchange in the United States and Britain to use risk management systems to protect the interests of stakeholders (Harrington, 2004).

Internal auditing plays a important role in risk management. Internal auditing is an independent function established by management to examine and evaluate the organization's risk management processes, control systems and corporate governance process and to provide recommendations for achieving the company's objectives (Roy, 2008). Although, according to the Smith and Turnbull Committee Guidance, management of organization is responsible for determining internal and external risks, but internal auditors help management in determining potential risk, risk assessment and determining the risky areas. Also, they provide an independent, objective opinion about the effects of criteria for response to risks, key controls, and whether the organization's risks have been reduced to an acceptable level or not. Risks should be determined by management, and there is no place for auditors to prepare such list of risks. Such list should applied by auditors at the end of the process of determining risk to ensure that all risks are determined. If internal audit conclude that management has not identified all significant risks, they should discuss the omissions with the management involved and if this does not resolve the issue, it should be reported to 
senior management, and the audit committee. Internal Audit should never be involved in any risk management activities that might compromise their independence and objectivity.

\section{Classification of organizations according to their risk maturity}

Each organization with short and long term objectives have internal and external risks. There are several of methods the organization can manage risks to bring them to a level which the board consider acceptable such as: avoid the risks, transfer them, tolerate them, without planning any contingencies (these are the 'asteroid hits earth' type of risk), Tolerate them, and plan contingencies, and finally introduce some processes to reduce the consequence or likelihood of a risk. These processes are usually referred to as a response to key risk or controls. Internal auditing has a major role in those types of organizations which are interested to plan for possible occurrence of risk, establish appropriate control to reduce and manage risks to an acceptable level.

The main purpose of internal auditing is to provide an independent and objective opinion to an organization's management as to whether its risks are being managed to acceptable levels. Internal auditing plays a major role in risk management in an organization with determined objectives. Internal auditing helps organization in determining potential risk, risk assessment and determining the risky areas, also, it provides an independent, objective opinion about the effects of criteria for response to risks, key controls, and whether the organization's risks have been reduced to an acceptable level or not. This is a continuous process. However, role and responsibility of risk based internal auditing in risk management in an organization are based on risk maturity. Companies can be classified based on their risk maturity as follows (Griffiths, 2006):

\subsection{Risk enabled}

In this case, risk management and internal control fully embedded into the operations. An understanding of the management of risk and the monitoring of controls will be very sophisticated in this organization. A complete risk register will be available for audit planning. Confidence in the risk management process should enable a range of auditing techniques to be used, from checking the management of individual risks, to those affecting a complete subsidiary. It is highly unlikely that internal audit work will find problems relating to (1) effectiveness of processes used by management to identify all significant risks, (2) correct assessment of important risks, (3) Evaluating risk management processes. The emphasis of the audit work will be that the risk management processes are working properly, in particular, that key risks are reported to the board and that monitoring of controls by managers is operating.

\subsection{Risk Managed}

Where enterprise-wide approach to risk management developed and communicated. It is similar to the risk enabled approach, except for, in some parts of the organization, it may be necessary to place more emphasis on above items listed in paragraph $(1,2$, and 3$)$. It may be necessary to facilitate management's proposed action where weaknesses are found.

\subsection{Risk Defined}

Where strategies and policies in place and communicated and risk appetite are defined. While most managers may have compiled lists of risks, it is possible that these will not be assembled into a complete risk register. The internal audit activity will act as a consultant to facilitate the compilation of a complete risk register from lists risks already compiled by managers. The quality of risk management may vary across this type of organization. Any individual audit therefore will have to place emphasis on understanding the level of risk maturity in the areas being audited. Where risk management is poor, internal auditing will have to facilitate the identification of risks, using workshops and interviews. There is more emphasis on items $1,2,3$. It is probable that some consultation work will be necessary to advise managers what action to take where weaknesses are found.

\subsection{Risk Aware}

They are organizations with scattered silo approach to risk management. In this organization, no risk register will be available, only a few managers will have determined their risks. Internal auditing 
will act as a consultant to undertake a risk assessment (in conjunction with management) to determine the work required to implement a risk framework that fulfils the requirements of the board. Also, using the key risks agreed with management, an audit/consultancy plan will be generated which aims to provide assurance that risks are being managed, or advice as to how to respond to them. Since this type of organization does not have a risk management framework, RBIA cannot be implemented. However, individual audits (as detailed in section 3.6) can be driven by risks where management understand risks, or internal audit have sufficient expertise to identify risks. Consultancy work will be necessary to advice on the actions to be taken where weaknesses are found.

\subsection{Risk Naive}

The organizations which have no formal approach for risk management are in this group. As with the risk aware organization, it will be necessary to promote, or provide consultation on, the establishment of a risk management framework for this organization. Until this is done RBIA cannot be implemented. Risk driven audits will be possible, but will require management training and risk workshops to determine risks in the areas concerned. Internal audit should not determine risks without management involvement, nor maintain their own list of risks. This will only reinforce management's belief that internal audit are responsible for risk management. For organizations that are subject to regulations concerning the adequacy of risk management, the level of risk maturity in risk aware and risk naïve organizations is not acceptable, and the audit committee should be aware of this. In all organization, except for risk enabled organization, internal auditing is responsible for risk assessment (consist of determining and classifying all potential risk), risk analysis, risk description, risk evaluation, and risk reporting. It seems that many Iranian companies and organizations are Risk Naive. So, the provided model in this research can play an important role in risk management process in them.

\section{Requirements for implementation of risk-based internal audit}

In this section, the most important requirements related to implementation of risk based internal auditing are provided.

\subsection{Identifying organizational purposes and processes}

Regarding the achievement of organization objective in different ways, all processes in organization should be documented. Since each process in practice has one or more subsidiary purpose, then the main process and purpose of organization should be dividend to subsidiary purposes and processes. In each process, related subsidiary purpose(s) and internal and external risks which may affect on this process are determined and classified. A detailed map of the process would be helpful in this work. The action of dividing process to secondary process (cycle) should be done to a place that internal auditor consider it a reasonable size for doing an audit. Therefore, any identified risks should be attributed to related process and purpose which facilitate creating audit units and therefore, preparing audit programs. The processes are used for classifying risks, and these processes should be reasonable and not necessarily real. By identifying risk in each level of process and linking them to main purpose and process, the auditor can be reasonably assured that all significant risk of organization has been determined. This way of considering risks in all process which assist in achievement of organization's goals, has the advantage of creating structure for risks. Risk assessment structure is actually useful for management to ensure that determined risks are complete or appropriate response have been created and risk management responsibilities have been assigned.

\subsection{Staff training and providing programs to increase their knowledge and technical ability}

One of the important challenges and problems related to acceptance and implementing new systems and technologies is lack of adequate understanding and knowledge to use those (Ngai et al., 2007). Therefore, increase in awareness and knowledge of users and organization's staff about features and way of using new 
systems and technologies can play significant role in accepting and implementing them in organization (Park et al., 2009). On this basis, one of the requirements for implementing risk-based internal control is training staff by department of internal auditing in organization about approach and various stages of implementing riskbased internal auditing. Also, given that managers and staff in various departments which are involved in the process play an important role in risk analysis (identification, determination and risk assessment, etc.), training workshop should be provided to them about methods of execution and implementation risk-based internal auditing. Furthermore, other staff should be aware from (familiar with) features and capabilities of new auditing model by different ways (including seminars, sending pamphlets and educational messages).

\subsection{Acceptance and support of senior management}

Acceptance and support of senior management is essential for successful implementation of new systems and technologies in the organizations.

\section{Empirical model for implementation of risk-based internal audit}

In this section the empirical model for implementation of risk-based internal auditing is provided. The model includes determining control objectives, analyzing and prioritizing risks, control activities (necessary requirements to reduce risks), determining existing control weaknesses, providing audit program, conducting the required tests, providing audit report. These are explained in more detailed in the following paragraphs. Regarding the necessity of analyzing risks and auditing of all organizational processes, the mentioned steps should be taken separately for all the processes.

\subsection{Determining control objectives}

As previously mentioned, each organizational process in addition to its role in achieving organizational objectives, also has certain objective(s) itself that should be identified and determined. In other words, each process is serving in achievement of certain purpose (objectives) which is its existing philosophy. For example, the main purpose of purchasing process is to provide required goods and services in accordance with the predetermined rules and regulations. In organizations may exist several types of purchasing processes (major, average and small), regarding to different steps and procedures of them, subsidiary process are created as each of them has certain objective. Yet, each of these processes (cycle) also may have secondary objective within itself. Determination of mentioned objectives (in level of process and cycle) normally requires identifying and documenting organizational processes which was mentioned previously as a prerequisite for implementation of risk-based internal audit.

\subsection{Analyzing and prioritizing risks}

Risk analysis consists of identifying and determining risks (potential risks), risk assessment and prioritizing them (determining estimated level) which are described as follows:

\subsubsection{Identifying and determining risks (potential risk)}

After determining control objectives (pervious section) all risks associated with each of these objectives should be identified and determined. Thus, the definition provided by Roy (2008) "risk is a set of events (circumstances) which may hinder achievement of the organization's objectives" can be very useful. Therefore, in order to determine risks related to each control objective, all conditions or factors (if the happen or exist) which may affect negatively the achievement of the organizational objectives should be identified.

\subsubsection{Risk assessing and ranking (risk assessment level)}

After determining the potential risks for each process/cycle, their probable effects on the achievement of control objectives and the probability of their occurrence should be determined. For evaluating and ranking risk and classifying potential risk, it is appropriate to determine or assign numerical values to each risk considering the potential effect and probability of their occurrence (Figure 1) and display (draw) them on a risks matrix (Figure 2). It should be noted that the evaluation method (assign numbers from 1 to 5) are optional 
Figure 1. Scoring risks

\begin{tabular}{|l|c|c|}
\hline \multicolumn{1}{|c|}{ If the consequence when the risk occurs is: } & $\begin{array}{c}\text { OR the likelihood } \\
\text { of the risk occurring is: }\end{array}$ & $\begin{array}{c}\text { Then the measure } \\
\text { is defined to be: }\end{array}$ \\
\hline $\begin{array}{l}\text { A catastrophic impact on the organisation, threatening its } \\
\text { existence }\end{array}$ & Almost certain & Catastrophic (5) \\
\hline $\begin{array}{l}\text { To prevent the organisation achieving all, or a major part, of } \\
\text { its objectives for a long time. }\end{array}$ & Probable & Major (4) \\
\hline $\begin{array}{l}\text { To stop the organisation achieving its objectives for a limi- } \\
\text { ted period. }\end{array}$ & Possible & Moderate (3) \\
\hline $\begin{array}{l}\text { To stop the organisation achieving its objectives for a limi- } \\
\text { ted period. }\end{array}$ & Unlikely & Minor (2) \\
\hline $\begin{array}{l}\text { To cause minor inconvenience, not affecting the achieve- } \\
\text { ment of objectives }\end{array}$ & Rare & Insignificant (1) \\
\hline
\end{tabular}

Source: Griffiths (2006).

Figure 2. Matrix showing the significance of risks

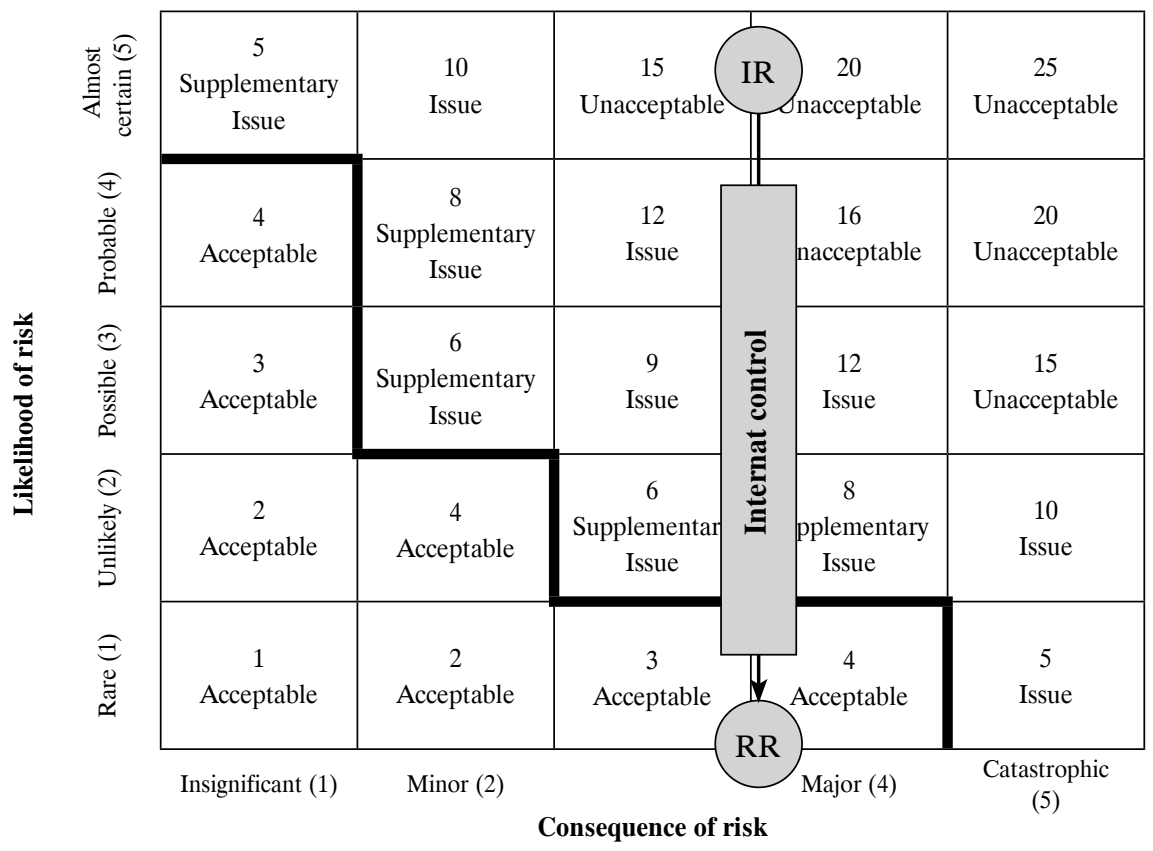

Unacceptable: Immediate action required to manage the risk

Issue: Action required to manage the risk

Supplementary issue: Action is advisable if resources are available

Acceptable: no action required

Risk appetite, as defined by the board

IR $=$ Inherent Risk $\quad$ RR $=$ Residual Risk

Source: Griffiths (2006). 
and other criteria (e.g., numbers 1 to 100 ) also can be used in this field. Also, given that statistically the probability of occurrence of an event is between zero and one, we can use percentages in this domain to assess the probability of occurrence (for example $20 \%, 30 \%$ etc.).

\subsection{Control activities (necessary requirements to reduce risks)}

As is shown in the risk matrix (Figure 2), the primary responsibility of internal control system is to reduce organizational risk levels to an acceptable level. In other word, internal control system should be able to protect organization against losses which result from different risks. Therefore, after the identification and assessment of organizational risks, the appropriate internal control should be appropriately determined. The existence of such methods (system) results in obtaining assurance regarding the reduction of risks and realization of long and short term objectives. As previously mentioned, internal control is a method to manage risk. In other words, controls are responses to risks.

\subsection{Determining existing control weaknesses}

After determining desirable internal control system (control activities), it is used as a criteria and indicator for evaluating and organizing existing (controls) system in organization. Existing control weaknesses actually shows non-conformities between these two systems (desirable and existing) which should be adjusted and improved. Experience acquire from implementing risk based internal auditing in one of large Iranian organizations shows that there are some risks for which there are no control activity to manage and control them. This results from lack of systematic and organized method of identifying and determining organizational risk and lack of designing an appropriate internal control system for them and also changes in objectives, business processes and organizations/companies environment which result in changes in related risks. To resolve this problem, the identified control weaknesses and proposed control activities should be reported to senior management and necessary decisions and actions to eliminate and improve them and use of proposed controls should be done. Also, organizational risk should be continually monitored and any changes in the objectives, processes and related risk be identified and necessary actions to manage them should be done.

\subsection{Providing audit program}

An audit program for each individual process/cycle to collect necessary evidences should be prepared and provided. Audit programs provide overall framework of audit area (name of process/cycle), audit period, purpose of investigation, date of preparation, audit team, sampling methods, organizational area of implementing program, and control procedure. Control procedures existing in audit program are key controls related to each control activity which its implementation results in reduced organizational risks to an acceptable level. Laws, regulations and rules governing and monitoring each process, provide related framework of control activities. Therefore, in order to provide audit program, all mentioned items should be studied and considered and key controls (according to identified risks) should be selected among them.

\subsection{Conducting examinations and providing audit report}

Risk-based internal auditing aims to assess inherent risks in each process and the effects of key existing controls and identify remained risks. In risk-based internal auditing process, audit program is used as guidance for operations and audit worksheet is used for documenting examinations and conducted actions and also collected evidences. The worksheet should have Completion Guide to provide necessary information for internal auditors to use this worksheet. A risk matrix may be used to make decision about priority or audit time period. Risks which are ranked high may be audited several times during the period while others may be audit each two or three years.

\section{Conclusions and recommendation}

Regarding to the role and importance of risk based internal auditing and various advantages of it in organizations and also lack of implementation of risk based internal auditing in many organizations and companies, it's necessary to develop a model in this regard. In response to this 
need, this paper provides a comprehensive and applicable model to implement and use risk based internal auditing. This model includes determining control objectives, analyzing and prioritizing risks, control activities (necessary requirements to reduce risks), determining existing control weaknesses, providing audit program, conducting the required tests, providing audit report. Using this model not only increase the effectiveness and efficiency of internal auditing, but also have a variety of benefits such as: providing the possibility and conditions of implementing risk based internal auditing, providing the possibility and conditions for conducting complete risk management, improving and updating internal control system by recognizing and identifying existing control weaknesses and taking adjusting actions, decreasing organization's risk taking, and finally decreasing cost of internal and independent auditing. Thus, we advice organizations and companies to accept, implement and use risk based internal auditing by using the provided model to take these advantages.

\section{Footnote}

1 Combined Code.

\section{References}

Basel Committee on Banking Supervision (2000). Internal audit in banking organizations and the relationship of the Supervisory authorities with internal and external auditors.

Basu, V., Hartono, E., Lederer, A.L. and Sethi, V. (2002). The impact of organizational commitment, senior management involvement and team involvement on strategic information systems planning. Information and Management, 39: 513-524.

Bou-Raad, G. (2000). Internal Auditors and a Value-Added Approach: The New Business Regime. Managerial Auditing Journal, 15(4): 182-186.

Brody, R.G. and Lowe, D.J. (2000). The New Role of Internal Auditor: Implications for Internal Auditor Objectivity. International Journal of Auditing, 4(2): 169-176.

Cooper, B.J., Leung, P. and Mathews, C. (1996). Benchmarking-a Comparison of Internal Audit in Australia, Malaysia and Hong Kong. Managerial Auditing Journal, 11(1): 23-29.

Dean, M., Feucht, S.J. and Smith, L.M. (2008). International Transfer Pricing Issues and Strategies for the Global Firm. Internal Auditing, 23(1): 12-19.
Deloitte (2005). Optimizing the Role of Internal Audit in the Sarbanes-Oxley Era. Available from: www.deloitte.com/dtt/cda/doc/content/us_ERS_ Internal20\% audit $20 \%$ POV.pdf.

Earl, M.J. (1993). Experiences in strategic information systems planning. MIS Quarterly, 22: 1-24.

Eden, D. and Moriah, L. (1996). Impact of Internal Auditing on Branch Bank Performance: A Field Experiment. Organization Behavior and Human Decision Processes, 68(3): 262-271.

Elahi, S., Abdi, B. and Shayan, A. (2006). E-Banking and Managerial Challenges: Change Management. First Annual Summit E-Banking. Teheran, Iran.

Gramling, A.A. (1999). External auditors' reliance on work performed by internal auditors: the influence of fee pressure on this reliance decision. Auditing: A Journal of Practice \& Theory, 18: 117-135.

Griffiths, D.M. (2006). Risk Base Internal Auditing-an Introduction. Available from: www.internalaudit.biz.

Harrington, C. (2004). Internal Audit's New Role. Journal of Accountancy, 198(3): 65-70.

Kamal, M.M. (2006). IT Innovation Adoption in the Government Sector: Identifying the Critical Success Factors. Journal of Enterprise Information Management, 19(2):192-222.

Leithhead, B.S. (2000). In touch with the top. Internal Auditor, 57.

Marche, S., and McNiven, J.D. (2003). "E-Government and E-Governance: The Future isn't what it used to be". Canadian Journal of Administrative Sciences (2), pp. 74-86.

Ngai, E.W.T., Poon, J.K.L. and Chan, Y.H.C. (2007). Empirical Examination of the Adoption of WebCT Using TAM. Computers \& Education, 48: 250-267.

Park, N., Roman, R., Lee, S. and Chung, J. (2009). User Acceptance of a Digital Library System in Developing Countries: An Application of the Technology Acceptance Model. International Journal of Information Management, 29: 196-209.

Rezaee, Z. (2009). Corporate Governance and Ethics. New York: John Wiley and Sons.

Roy, A.K. (2008). Risk Based Internal Audit-Need for Such Approach in Banking Sector for Implementation of Basel Ii Accord: Bangladesh Perspective. The Bangladesh Accountant, July-September

Schneider, A. and Wilner, N. (1990). A Test of Audit Deterrence to Financial Reporting Irregularities Using Randomized Response Technique. The Accounting Review, 65(3): 668-681.

Smith, L.M. (2006). Audit Committee Effectiveness: Did the Blue Ribbon Committee Recommen- 
dations Make a Difference? International Journal of Accounting, Auditing and Performance Evaluation, 3(2): 240-251.

Spira, L.F. and Page, M. (2003). Risk Management: The Reinvention of Internal Control and the Changing Role of Internal Audit, Accounting Auditing and Accountability Journal, 16 (4): 640-661.
Wallace, W.A. (1984). A Time Series Analysis of the Effect of Internal Audit Activities on External Audit Fees. Altamonte Spring, FL: Institute of Internal Auditors.

Warren, D. and Smith, L.M. (2006). Continuous Auditing: An Effective Tool for Internal Auditors. Internal Auditing, 21(2): 27-35. 